\title{
Molecular characterization of the species Salvinia (Salviniaceae) from the upper Paraná River floodplain
}

\author{
S.A. Machado ${ }^{1}$, A.V. Oliveira ${ }^{3,4}$, T.M.C. Fabrin ${ }^{2,3}$, S.M.A.P. Prioli ${ }^{3,4}$ and \\ A.J. Prioli ${ }^{3}$ \\ ${ }^{1}$ Programa de Pós-Graduação em Biologia Comparada, \\ Universidade Estadual de Maringá, PR, Brasil \\ ${ }^{2}$ Programa de Pós-Graduação em Ecologia de Ambientes Aquáticos Continentais, \\ Universidade Estadual de Maringá, PR, Brasil \\ ${ }^{3}$ Núcleo de Pesquisa em Limnologia, Ictiologia e Aquicultura, \\ Universidade Estadual de Maringá, Maringá, PR, Brasil \\ ${ }^{4}$ Departamento de Biotecnologia, Genética e Biologia Celular, \\ Universidade Estadual de Maringá, Maringá, PR, Brasil \\ Corresponding author: A.V. Oliveira \\ E-mail: alessoli@hotmail.com
}

Genet. Mol. Res. 15 (3): gmr. 15038575

Received February 23, 2016

Accepted April 11, 2016

Published August 12, 2016

DOI http://dx.doi.org/10.4238/gmr.15038575

Copyright (C) 2016 The Authors. This is an open-access article distributed under the terms of the Creative Commons Attribution ShareAlike (CC BY-SA) 4.0 License.

\begin{abstract}
The pteridophytes Salvinia minima, S. herzogii, and $S$. auriculata are among the most abundant aquatic macrophytes in the upper Paraná River floodplain. Since some species have highly similar morphological features, it is very difficult to identify members of this genus to the species level. An indication of this difficulty is a set of poorly differentiated taxa comprising $S$. auriculata and $S$. herzogii known as the ' $S$. auriculata complex', which is found in the Paraná River together with other Salvinia species such as $S$. biloba and $S$.
\end{abstract}


molesta. Some authors have reported the existence of inter-species hybrids. Despite the complex Salvinia taxonomy, few genetic studies have been performed on purported species within the genus to resolve this complexity. The present study was conducted to determine useful molecular sequences for the discrimination of Salvinia species of the upper Paraná River floodplain. Molecular data were compared with data of other species of the genus to clarify phylogenetic relationships, employing the nucleotide sequence trnL-trnF from the chloroplast DNA. The results revealed that Salvinia populations in the upper Paraná River floodplain belong to different species and indicated that species of the $S$. auriculata complex may be distinguished from one another after the division of the $S$. minima group, corroborating results by other researchers. Although the taxonomic position of $S$. oblongifolia was clarified, as high closeness between S. oblongifolia and the S. auriculata complex was reported, Salvinia kinship is still not thoroughly established and further investigations in morphology and molecular diversity are required.

Key words: Chloroplast DNA; Aquatic macrophytes; Salvinia; trnL-trnF

\section{INTRODUCTION}

Aquatic macrophytes include plants in the aquatic environment that are visible to the naked eye. Their active photosynthetizing segments may be seen floating, or totally or partially submerged, permanently or for several months, in fresh or saline water (Irgang and Gastal $\mathrm{Jr}, 1996$ ). Their taxonomic identification is often vague, since this vegetation comprises a great variety of growth habits coupled with great phenotypic plasticity that makes difficult the identification of the species. Some of these morpho-anatomical variations may have adaptive features (Sculthorpe, 1985).

During the last decades, studies on the ecology, importance, and management of water macrophytes have developed considerably in Brazil. This is especially true with regard to great reservoirs due to the real and potential problems in the development of this type of vegetation. Because they may impede navigation and hydroelectric power generation, water macrophytes are often considered weeds (Thomaz et al., 1998; Thomaz and Bini, 1999).

The upper Paraná River floodplain, an important stretch of the Paraná River that flows through the northwestern region of the State of Paraná and the southeastern region of the State of Mato Grosso do Sul, Brazil, is still undammed. Several studies on water macrophytes have been developed in the upper Paraná River floodplain by the researchers of the Research Nucleus in Limnology, Ichthyology, and Aquaculture (NUPELIA) of Universidade Estadual de Maringá (UEM), Maringá, PR, Brazil. Salvinia species are among the most abundant macrophytes in the region (Sidinei Magela Thomaz and Thomaz Aurélio Pagioro, personal communication).

The genus Salvinia of the family Salviniaceae comprises approximately 12 species (Tryon and Tryon, 1982; Cook, 1990; Schneller, 1990; Pereira, 1999), seven of which have been reported in the Americas (Tryon and Tryon, 1982). Specimens collected in the upper Paraná

Genetics and Molecular Research 15 (3): gmr.15038575 
River were previously identified as Salvinia auriculata, S. herzogii, and S. minima, which may be found coexisting in the same lake. However, botanical identification and discrimination of S. auriculata and S. herzogii are difficult due to their highly similar morphologies. The floating leaf of the $S$. auriculata features hair united in its extremities in the shape of a mixer paddle, similar to $S$. herzogii. However, modified leaf trichomes of $S$. auriculata are derived from a U-shaped structure (Pott and Pott, 2000), whereas the trichomes of S. herzogii are derived from a spherical structure (Irgang and Gastal Jr, 1996; Pott and Pott, 2000). S. minima features Y-shaped hairs in its floating leaves, and trichomes in its modified leaves derive from the same structure as that in S. herzogii.

The $S$. auriculata complex is indicative of the difficulties in identifying Salvinia species (Mitchell and Thomas, 1972; Forno, 1983). According to Velásquez (1994), plants identified as $S$. auriculata probably belong to a complex of species and subspecies that have highly similar vegetative morphology. The $S$. auriculata complex would include $S$. auriculata, S. herzogii, S. biloba, S. molesta, and perhaps other taxa yet to be described. Herzog (1935), greatly contributing to the description of Salvinia taxonomy, did not differentiate between these species, and all were identified as $S$. auriculata. It is possible that $S$. auriculata populations in the floodplain may be subjected to similar taxonomic confusion.

The occurrence of interspecies hybrids, registered by Cook (1990) and Sota and Pazos (2001), is another complicating factor in species identification. The aggressive species $S$. molesta, originally identified as $S$. auriculata, has intermediate characteristics expected from a hybrid between $S$. biloba and $S$. herzogii, coupled to its possible great adaptability (Mitchell and Thomas, 1972; Schneller, 1990).

In view of the group's complexity, Salvinia taxonomy is a tricky field and all types of information may be useful and may contribute towards a consistent taxonomy; however, the literature contains few molecular analyses to determine genetic distances or phylogenetic relationships between species of Salvinia. Most previous studies include Salvinia species in the phylogenetic analysis of broader pteridophyte groups (Hasebe et al., 1994; Pryer et al., 1995, 2001, 2004; Korall et al., 2006; Schuettpelz and Pryer, 2006, 2007) and as an outgroup for the establishment of the related Azolla phylogeny (Reid et al., 2006; Metzgar et al., 2007). Some studies have been conducted on individual Salvinia species. Studies on the genetic diversity of $S$. minima populations in southern USA with random amplified polymorphic DNA (RAPD) molecular markers and in S. molesta by amplified fragment-length polymorphism (AFLP) and $g a p C p$ were performed by Madeira et al. (2003) and Galam et al. (2015), respectively. However, to our knowledge, only one study (Nagalingum et al., 2008) has established the phylogenetic relationships between multiple Salvinia taxa, including American and Eurasian species.

Recent studies have successfully clarified phylogenetic relationships between plant species by employing non-codifying sequences of nuclear and chloroplast DNA (e.g., Wall and Herbeck, 2003; Smith et al., 2006). Among such sequences, use of the intergenic spacer localized between genes $t R N A^{\text {Leu }}$ and $t R N A^{\text {Phe }}$ of the chloroplast DNA (cpDNA), usually called the $\operatorname{trn} L-\operatorname{trn} F$ region, has been frequent. Since it is an intergenic spacer, the nucleotide sequence is not a codifier. Among the higher plants, the sequence has been useful in the identification of leguminous species of the genus Swartzia (Torke and Schaal, 2008), the grasses of the genus Genea (Fortune et al., 2008), and others. Most importantly for the present study, the region has been effective for the discrimination of species and the definition of phylogeny in several pteridophytes, including Polystichum (Li et al., 2008), Azolla (Reid et al., 2006; Metzgar et al., 2007), and Salvinia (Nagalingum et al., 2008).

Genetics and Molecular Research 15 (3): gmr.15038575 
To address the problems in Salvinia taxonomy, the present study was performed to obtain useful molecular sequences for the discrimination of Salvinia species of the upper Paraná River floodplain. These molecular data were compared with data derived from other species of the genus to identify phylogenetic relationships based upon the $\operatorname{trnL-trnF}$ region of the cpDNA.

\section{MATERIAL AND METHODS}

\section{Sampling and DNA extraction}

The species $S$. auriculata $(\mathrm{n}=5), S$. herzogii $(\mathrm{n}=5)$, and $S$. minima $(\mathrm{n}=5)$ were sampled at two sites in the upper Paraná River floodplain, namely, Garças Lagoon $\left(22^{\circ} 43^{\prime} 33^{\prime \prime} \mathrm{S} ; 53^{\circ} 13^{\prime} 35^{\prime \prime} \mathrm{W}\right)$ and Pau-Véio backwater $\left(22^{\circ} 44^{\prime} 52^{\prime \prime} \mathrm{S} ; 53^{\circ} 15^{\prime} 04^{\prime \prime} \mathrm{W}\right)$ (Figure 1). The species were identified and transported in plastic bags filled with water and placed in a polystyrene foam container until DNA extraction at the Genetic Laboratory of NUPELIA at UEM, Maringá, PR, Brazil.
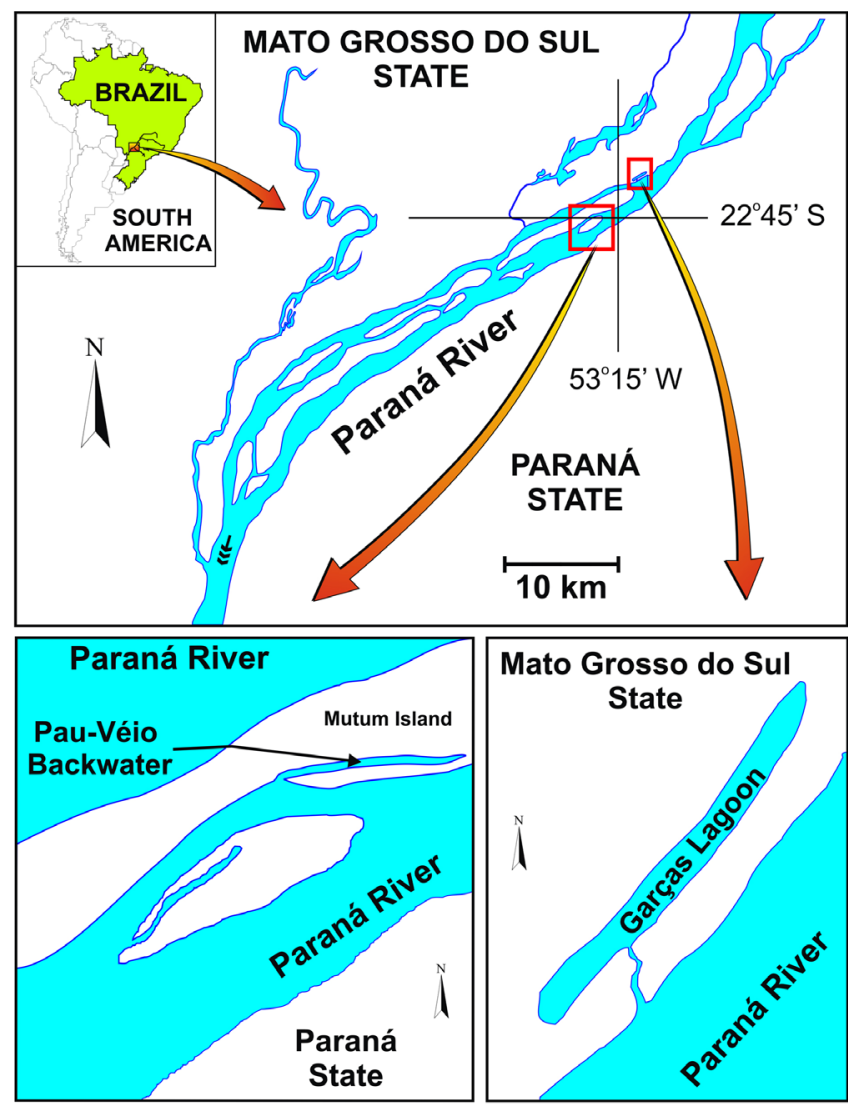

Figure 1. Collection sites of Salvinia specimens in the upper Paraná River floodplain. 
DNA was extracted from samples according to the method of Murray and Thompson (1980), with modifications. The leaves were ground with liquid nitrogen in an earthenware mortar. Extraction buffer (2\% CTAB; $1.4 \mathrm{M} \mathrm{NaCl} ; 100 \mathrm{mM}$ Tris-HCl, $\mathrm{pH}$ 8.0; 20 mM EDTA; $0.2 \% \beta$-mercaptoethanol) was added to the frozen ground substance and placed in a warm bath at $60^{\circ} \mathrm{C}$ for approximately $30 \mathrm{~min}$. Next, the DNA from each sample was washed with Sevag (chlorophorm:isoamyl alcohol 24:1) and $100 \%$ ethanol, and re-suspended in TE buffer (10 mM Tris-HCl, $\mathrm{pH} 8.0 ; 1 \mathrm{mM}$ EDTA). The amount of DNA in each sample was estimated by comparison with known amounts of phage lambda DNA using agarose gel $(0.8 \%)$ electrophoresis.

\section{PCR and DNA sequencing}

The nucleotide sequence between $t R N A^{\mathrm{Leu}}$ and $t R N A^{\mathrm{Phe}}$ of the cpDNA was amplified by primers $t r n-c-F$ (5'-GGAAATCGGTAGACGCTACG-3') and trn-f-R (5'-ATTTGAACTGGTGACACGAG-3') (Reid et al., 2006). Polymerase chain reaction (PCR) was performed in a solution of Tris-KCl $(20 \mathrm{mM}$ Tris- $\mathrm{HCl} \mathrm{pH} \mathrm{8.4;50} \mathrm{mM} \mathrm{KCl}), 1.5 \mathrm{mM}$ $\mathrm{MgCl}_{2}, 2.5 \mu \mathrm{M}$ of each primer, $0.1 \mathrm{mM}$ of each dNTP, $1 \mathrm{U}$ Taq DNA polymerase, $15 \mathrm{ng}$ template DNA, and deionized and filtered water (MilliQ) to make the volume to $25 \mu \mathrm{L}$.

Amplification reactions followed the following program: 1 initial cycle of $4 \mathrm{~min}$ at $92^{\circ} \mathrm{C}$; 40 cycles at $94^{\circ} \mathrm{C}$ for $15 \mathrm{~s}, 59^{\circ} \mathrm{C}$ for $30 \mathrm{~s}$, and $72^{\circ} \mathrm{C}$ for $2 \mathrm{~min}$; followed by a final extension at $72^{\circ} \mathrm{C}$ for $10 \mathrm{~min}$. Negative controls were employed with each amplification set. Aliquots from the reaction product of each sample were fractionated on a $1 \%$ agarose gel. The size of each fragment was determined by comparison with bands of a standard 100-bp ladder (Invitrogen Life Technologies, Carlsbad, CA, USA).

Approximately 50 ng DNA from each purified PCR product were employed as a template for sequencing with primer trn-c-F and, separately, with primer trn-f-R. Sequencing was performed on the MegaBace platform (Amersham) following manufacturer instructions. Since reliable sequences of $S$. minima from the upper Paraná River floodplain could not be obtained due to sequencing problems, DNA sequences of $S$. auriculata and $S$. herzogii were analyzed.

\section{Phylogenetic analysis}

Sequences were manually edited with BioEdit (Hall, 1999) and then aligned using the ClustalW algorithm with MEGA 6 (Tamura et al., 2013). Sequences of the intergenic spacer $\operatorname{trnL-trnF}$ derived from other species in the genus Salvinia, retrieved from GenBank, were also used in the phylogenetic analysis (Table 1). Appropriate nucleotide substitution models were estimated by jModelTest 2 (Darriba et al., 2012), taking into consideration Bayesian Information Criterion and Akaike Information Criterion.

A phylogenetic tree was constructed based upon maximum likelihood analysis and Bayesian statistics with the programs raxmlIGUI (Silvestro and Michalak, 2012) and BEAST (Drummond et al., 2012), respectively, to verify the phylogenetic positions of the Salvinia species in the upper Paraná River floodplain. One thousand bootstrap re-samplings were used for maximum likelihood analysis, with rates above $70 \%$ defined as good support. Bayesian analysis was performed twice and separately. The chains were later combined with a minimum effective size rate of 200 , indicating chain convergence. The first $10 \%$ of the chain was

Genetics and Molecular Research 15 (3): gmr.15038575 
discarded as 'burn-in'. Branches with $95 \%$ or more a posteriori probability were considered to have good support.

Table 1. Species, locality (if known), GenBank accession (if available), and references for the nucleotide sequences used in phylogenetic analysis of the genus Salvinia.

\begin{tabular}{l|l|l|l}
\hline Species & Locality & GenBank & Reference \\
\hline Salvinia auriculata & Upper Paraná River, Brazil & - & This paper \\
\hline S. herzogii & Upper Paraná River, Brazil & - & This paper \\
\hline S. minima $(1)$ & United States & EU269686 & Nagalingum et al. (2008) \\
\hline S. minima $(2)$ & Unknown & EU269687 & Nagalingum et al. (2008) \\
\hline S. molesta $(1)$ & Unknown & EU269688 & Nagalingum et al. (2008) \\
\hline S. molesta $(1)$ & Costa Rica & EU269689 & Nagalingum et al. (2008) \\
\hline S. natans $(1)$ & Germany & EU269690 & Nagalingum et al. (2008) \\
\hline S. natans $(2)$ & China & EU269691 & Nagalingum et al. (2008) \\
\hline S. oblongifolia $(1)$ & Germany & AY651839 & Quandt et al. (2004) \\
\hline S. oblongifolia $(2)$ & Unknown & EU269693 & Nagalingum et al. (2008) \\
\hline S. oblongifolia $(3)$ & Unknown & EU269692 & Nagalingum et al. (2008) \\
\hline Salvinia sp & - & DQ066503 & Reid et al. (2006) \\
\hline & & &
\end{tabular}

\section{RESULTS}

The molecular marker sequence $\operatorname{trnL}$-trnF ( $750 \mathrm{bp}$ ) was amplified for each Salvinia species from the upper Paraná River floodplain. The sequences obtained corresponded to a section of $t R N A^{L e u}$ and to a section of the intergenic spacer trnL-trnF. The segment was sufficient to differentiate the species.

The nucleotide composition of the marker comprises $29.9 \% \mathrm{~T}, 19.2 \% \mathrm{C}, 30.6 \% \mathrm{~A}$, and $20.3 \%$ G. Sequence analysis indicates that $8.1 \%$ of the 750 bases correspond to informative sites. Of the variable sites identified, $46 \%$ are transversions and $54 \%$ transitions; the ratio of transition to transversion is 1.09 .

The best-fit nucleotide substitution model was HKY (Hasegawa-Kishino-Yano) + G (Hasegawa et al., 1985); the substitution model used to construct the phylogenetic tree was GTR (general time reversible) + G (Rodríguez et al., 1990), that is rather complex than other substitution models and takes into account several parameters. A more elaborate model could be expected due to the non-codified sequence under analysis and the differentiation between the Salvinia species.

Among the Salvinia species, genetic distance rates from the partial $\operatorname{trn} L$-trnF sequence of all the species analyzed range between 0.3 and $8.4 \%$. As expected, distances are higher between Salvinia species and the outgroup Pilularia americana (GenBank accesssion No. EU269725), ranging between 39.7 and 41.5\%.

Figure 2 shows the phylogenetic position of the species $S$. auriculata and S. herzogii from the upper Paraná River floodplain compared to other species of the genus and taking into account the statistical methods of maximum likelihood and Bayesian inference. Following the phylogeny provided, three very distinct clades are formed for Salvinia natans, S. minima, and species of the $S$. auriculata group ( $S$. auriculata and $S$. herzogii of the upper Paraná River floodplain, plus S. molesta) (Mitchell and Thomas, 1972; Forno, 1983). Salvinia oblongifolia is positioned in the $S$. auriculata group, next to $S$. auriculata. Although specimens within the $S$. auriculata group are genetically close, distance rates between $S$. auriculata and $S$. herzogii (2.5\%) of the upper Paraná River floodplain indicate different species.

Genetics and Molecular Research 15 (3): gmr.15038575 


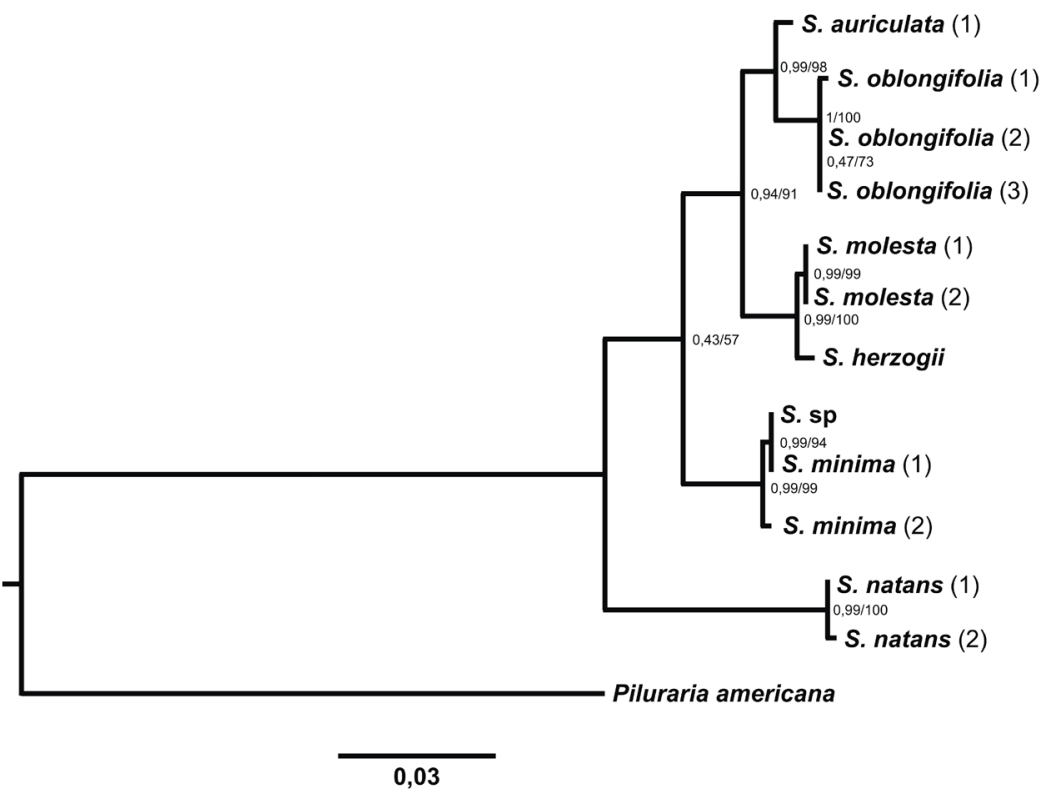

Figure 2. Phylogenetic tree of the species of the genus Salvinia. Branch supports correspond to posterior probability/ bootstrap analysis, respectively.

High bootstrap rates are consistent with almost all clades, the exception is S. minima, with rates less than 50 . Genetic distances were mostly compatible with distances between closely related species. Genetic distances between the $S$. minima group and the $S$. auriculata group, including S. oblongifolia, varied between 3.7 and $4.5 \%$, according to correction by nucleotide substitution model Kimura-2-parameters (Kimura, 1980). Distances ranged between 7.4 and $8.4 \%$ between $S$. natans and the $S$. auriculata group, whereas there were low genetic distance rates within the $S$. auriculata group between $S$. herzogii and $S$. molesta $(0.3 \%)$ and within the $S$. minima group between S. minima and the unnamed Salvinia sp (0.003\%).

\section{DISCUSSION}

Extant literature provides few studies on the genetic analysis of Salvinia species. The present study provides an in-depth understanding of genetic relationships within the genus. The intergenic spacer $\operatorname{trn} L$-trnF produced sufficient polymorphism at adequate levels for analysis, confirming reports that indicate spacer $\operatorname{trnL} L \operatorname{trn} F$ is polymorphic and useful for the evaluation of closely-related species (Shaw et al., 2005; Small et al., 2005; Reid et al., 2006; Metzgar et al., 2007), as in the case of Salvinia.

According to the phylogeny, the species $S$. auriculata and $S$. herzogii of the upper Paraná River floodplain belong to a well-supported clade, similar to taxonomy based on morphological characteristics, which positions the two species within the $S$. auriculata complex. The results of the present study corroborate the status of the species of the members of the $S$. auriculata complex, in spite of subtle morphological differences (Mitchell and Thomas, 1972; Velásquez, 1994). High bootstrap and a posteriori probability rates, respectively, for

Genetics and Molecular Research 15 (3): gmr.15038575 
maximum likelihood analysis and by Bayesian inference foreground the clades. Genetic distances for $S$. auriculata and $S$. herzogii $(2.5 \%)$ of the upper Paraná River floodplain $S$. auriculata complex also evidence separate species.

Studies by the molecular genetic laboratory team of NUPELIA on S. auriculata, $S$. herzogii, and $S$. minima, employing RAPD, provided species-specific nuclear molecular markers. The genetic distance of $S$. minima when compared to $S$. auriculata and $S$. herzogii became evident, since $S$. minima did not share fragments with the other two species. On the other hand, S. auriculata and S. herzogii displayed DNA fragments and species-specific markers which corroborated the hypothesis that they belong to separate, yet closely related species (Alberto José Prioli, personal communication). Specimens with markers of the two species were not detected in the RAPD study and indicate reproductive isolation between $S$. auriculata and $S$. herzogii. Differentiation between $S$. auriculata and $S$. herzogii derived from the chloroplast markers used in the present study showed high unlikelihood of hybridization.

Unexpectedly, S. oblongifolia was positioned within the clade of the S. auriculata complex. According to Mitchell and Thomas (1972) and Forno (1983), the S. auriculata complex should include $S$. auriculata, S. herzogii, S. biloba, and S. molesta, but should not include $S$. oblongifolia. It should therefore be highlighted that, according to the results of the present study, S. auriculata is closer to S. oblongifolia than to S. herzogii and S. molesta. Velásquez (1994) underscores that plants identified as $S$. auriculata probably belong to very similar species complex in vegetative morphology. The present results seem to show that evolution of the $S$. auriculata complex should take into account $S$. oblongifolia. Further, $S$. auriculata and $S$. oblongifolia are species with wide geographic distributions and, along with other species of the S. auriculata group occurring in South America, reveal the study region to be highly diversified in Salvinia spp (Mitchell and Thomas, 1972; Forno, 1983; Sota and Cassa de Pazos, 1992). Further studies on the relationship between the two species should reveal their spatial variation, which will likely reveal other unknown species currently identified either as S. auriculata or as S. oblongifolia.

Data also show high genetic closeness between $S$. herzogii and S. molesta $(0.3 \%)$. In the case of $S$. molesta, several authors report that it has intermediary characteristics expected from a S. biloba-S. herzogii hybrid (Mitchell and Thomas, 1972; Schneller, 1990), coupled to possible hybrid strength. The present study evidences a genetic similarity between $S$. molesta and $S$. herzogii, although molecular analysis including nuclear markers and S. biloba sequences would be necessary to reveal hybridization events. Other assays include $S$. molesta in phylogenies within the genus Salvinia, excepting S. herzogii (Nagalingum et al., 2008) and in population studies. Galam et al. (2015) analyzed S. molesta in Louisiana and Texas with AFLP molecular markers and the gapC $p$ gene, and detected significant levels of genetic variation in the population studied.

S. natans was the most basal species among the Salvinia group analyzed within the phylogenetic tree, followed by $S$. minima and an unnamed Salvinia sp. According to data retrieved by trnL-trnF markers in present study, the unnamed Salvinia sp probably belongs to S. minima, due to its genetic distance rates $(0.003 \%)$. Species of the S. auriculata complex were more distant from the outgroup Pilularia. Therefore, the $S$. auriculata complex of neotropical species would have originated later within the evolution scenario of Salvinia. Studies on the phylogenetic relationships in Salvinia by Nagalingum et al. (2008), employing six regions of chloroplast DNA, also evidenced a clade made up of S. minima as a sister-group consisting of $S$. molesta and S. oblongifolia and a second clade including specimens of S. natans. In the 
present study, the sequences of $\operatorname{trn} L-\operatorname{trn} F$ region of chloroplast DNA were useful to establish the same evolution patterns in Salvinia, already revealed in combinations with other molecular markers.

The comparisons between sequences of the $\operatorname{trn} L-\operatorname{trn} F$ region of cpDNA reveal that populations of Salvinia of the upper Paraná River floodplain are different species (S. herzogii and $S$. auriculata) and confirm the preliminary morphological analysis of the groups. Further, species of the S. auriculata complex differentiated after the separation of the S. minima group. The unexpected close kinship of $S$. oblongifolia to the $S$. auriculata complex in the present study suggests that Salvinia taxonomy is still unclear. Further phylogenetics investigations should be proposed that feature more molecular data, possibly based on paleontological information.

\section{Conflicts of interest}

The authors declare no conflict of interest.

\section{ACKNOWLEDGMENTS}

The authors would like to thank Sidnei Magela Thomaz and Thomaz Aurélio Pagioro for assistance with Salvinia sampling and species identification, NUPELIA-UEM for logistical support, and CNPq - PELD (site 6). S.A. Machado was the recipient of a CAPES fellowship.

\section{REFERENCES}

Cook CDK (1990). Aquatic Plant Book. SPB Academic Publishing, The Hague, The Netherlands.

Darriba D, Taboada GL, Doallo R and Posada D (2012). jModelTest 2: more models, new heuristics and parallel computing. Nat. Methods 9: 772. http://dx.doi.org/10.1038/nmeth.2109

Drummond AJ, Suchard MA, Xie D and Rambaut A (2012). Bayesian phylogenetics with BEAUti and the BEAST 1.7. Mol. Biol. Evol. 29: 1969-1973. http://dx.doi.org/10.1093/molbev/mss075

Forno IW (1983). Native distribution of the Salvinia auriculata complex and keys to species identification. Aquat. Bot. 17: 71-83. http://dx.doi.org/10.1016/0304-3770(83)90019-0

Fortune PM, Pourtau N, Viron N and Ainouche ML (2008). Molecular phylogeny and reticulate origins of the polyploid Bromus species from section Genea (Poaceae). Am. J. Bot. 95: 454-464. http://dx.doi.org/10.3732/ajb.95.4.454

Galam D, Silva J, Sanders D and Oard JH (2015). Morphological and genetic survey of Giant Salvinia populations in Louisiana and Texas. Aquat. Bot. 127: 20-25. http://dx.doi.org/10.1016/j.aquabot.2015.07.005

Hall TA (1999). BioEdit: a user-friendly biological sequence alignment editor and analysis program for Windows 95/98/ NT. Nucleic Acids Symp. Ser. 41: 95-98.

Hasegawa M, Kishino H and Yano T (1985). Dating of the human-ape splitting by a molecular clock of mitochondrial DNA. J. Mol. Evol. 22: 160-174. http://dx.doi.org/10.1007/BF02101694

Hasebe M, Omori T, Nakazawa M, Sano T, et al. (1994). $r b c L$ gene sequences provide evidence for the evolutionary lineages of leptosporangiate ferns. Proc. Natl. Acad. Sci. USA 91: 5730-5734. http://dx.doi.org/10.1073/pnas.91.12.5730

Herzog R (1935). Ein Beitrag zur Systematik der Gattung Salvinia. Hedwigia 74: 257-284.

Irgang BE and Gasttal Jr CVS (1996). Macrófitas Aquáticas da Planície Costeira do RS. CPG-Botânica/ UFRGS, Porto Alegre.

Kimura M (1980). A simple method for estimating evolutionary rates of base substitutions through comparative studies of nucleotide sequences. J. Mol. Evol. 16: 111-120. http://dx.doi.org/10.1007/BF01731581

Korall P, Conant DS, Schneider H, Ueda K, et al. (2006). On the phylogenetic position of Cystodium: it's not a tree fern it's a polypod! Am. Fern J. 96: 45-53. http://dx.doi.org/10.1640/0002-8444(2006)96[45:OTPPOC]2.0.CO;2

Li C-X, Lu S-G and Barrington DS (2008). Phylogeny of Chinese Polystichum (Dryopteridaceae) based on chloroplast DNA sequence data (trnL-F and rps4-trnS). J. Plant Res. 121: 19-26. http://dx.doi.org/10.1007/s10265-007-0120-1

Genetics and Molecular Research 15 (3): gmr.15038575 
Madeira PT, Jacono CC, Tipping P, Van TK, et al. (2003). A genetic survey of Salvinia minima in the southern United States. Aquat. Bot. 76: 127-139. http://dx.doi.org/10.1016/S0304-3770(03)00036-6

Metzgar JS, Schneider H and Pryer KM (2007). Phylogeny and divergence time estimates for the fern genus Azolla (Salviniaceae). Int. J. Plant Sci. 168: 1045-1053. http://dx.doi.org/10.1086/519007

Mitchell DS and Thomas PA (1972). Ecology of water weeds in the neotropics. Unesco Tech. Paper in Hydrology 12: 34-44.

Murray MG and Thompson WF (1980). Rapid isolation of high molecular weight plant DNA. Nucleic Acids Res. 8: 43214326. http://dx.doi.org/10.1093/nar/8.19.4321

Nagalingum NS, Nowak MD and Pryer KM (2008). Assessing phylogenetic relationships in extant heterosporous ferns (Salviniales), with a focus on Pilularia and Salvinia. Bot. J. Linn. Soc. 157: 673-685. http://dx.doi.org/10.1111/ j.1095-8339.2008.00806.x

Pereira AB (1999) Introdução ao Estudo das Pteridófitas. Editora da Ulbra, Canoas.

Pott VJ and Pott A (2000). Plantas Aquáticas do Pantanal. Embrapa Comunicação para Transferência de Tecnologia, Brasília.

Pryer KM, Smith AR and Skog JE (1995). Phylogenetic relationships of extant ferns based on evidence from morphology and $r b c L$ sequences. Am. Fern J. 85: 205-282. http://dx.doi.org/10.2307/1547810

Pryer KM, Schneider H, Smith AR, Cranfill R, et al. (2001). Horsetails and ferns are a monophyletic group and the closest living relatives to seed plants. Nature 409: 618-622. http://dx.doi.org/10.1038/35054555

Pryer KM, Schuettpelz E, Wolf PG, Schneider H, et al. (2004). Phylogeny and evolution of ferns (monilophytes) with a focus on the early leptosporangiate divergences. Am. J. Bot. 91: 1582-1598. http://dx.doi.org/10.3732/ajb.91.10.1582

Quandt D, Müller K, Stech M, Frahm JP, et al. (2004). Molecular evolution of the chloroplast Trnl-F region in land plants. Monogr. Syst. Bot. Missouri Botanic Garden 98: 13-37.

Reid JD, Plunkett GM and Peters GA (2006). Phylogenetic relationships in the heterosporous fern genus Azolla (Azollaceae) based on DNA sequence data from three noncoding regions. Int. J. Plant Sci. 167: 529-538. http:// dx.doi.org/10.1086/501071

Rodríguez F, Oliver JL, Marín A and Medina JR (1990). The general stochastic model of nucleotide substitution. J. Theor. Biol. 142: 485-501. http://dx.doi.org/10.1016/S0022-5193(05)80104-3

Schneller JJ (1990). Salvinaceae. In: The Family and Genera of Vascular Plants Vol 1: Pteridophytes and Gymnosperms (Kubitzki K, Kramer KU and Green PS, eds.). Springer, Berlin, 256-258.

Schuettpelz E and Pryer KM (2006). Reconciling extreme branch length differences: decoupling time and rate through the evolutionary history of filmy ferns. Syst. Biol. 55: 485-502. http://dx.doi.org/10.1080/10635150600755438

Schuettpelz E and Pryer KM (2007). Fern phylogeny inferred from 400 leptosporangiate species and three plastid genes. Taxon 56: 1037-1050. http://dx.doi.org/10.2307/25065903

Sculthorpe CD (1985). The biology of aquatic vascular plants. Koeltz Scientific Books, Germany.

Shaw J, Lickey EB, Beck JT, Farmer SB, et al. (2005). The tortoise and the hare II: relative utility of 21 noncoding chloroplast DNA sequences for phylogenetic analysis. Am. J. Bot. 92: 142-166. http://dx.doi.org/10.3732/ajb.92.1.142

Silvestro D and Michalak I (2012). RaxmlGUI: A graphical front-end for RAxML. Org. Divers. Evol. 12: 335-337. http:// dx.doi.org/10.1007/s13127-011-0056-0

Small RL, Lickey EB, Shaw J and Hauk WD (2005). Amplification of noncoding chloroplast DNA for phylogenetic studies in lycophytes and monilophytes with a comparative example of relative phylogenetic utility from Ophioglossaceae. Mol. Phylogenet. Evol. 36: 509-522. http://dx.doi.org/10.1016/j.ympev.2005.04.018

Smith AR, Pryer KM, Schuettpelz E, Korall P, et al. (2006). A classification for extant ferns. Taxon 55: 705-731. http:// dx.doi.org/10.2307/25065646

Sota ER and Cassa de Pazos LA (1992). Contribución al conocimiento de las Salviniaceae Neotropicales VI: Salvinia martynii. Darwiniana 13: 529-536.

Sota ER and Pazos LAC (2001). Two cytotypes and a new hybrid in Salvinia Seguier. Acta Amazon. 314: 557-564. http:// dx.doi.org/10.1590/1809-43922001314564

Tamura K, Stecher G, Peterson D, Filipski A, et al. (2013). MEGA6: Molecular Evolutionary Genetics Analysis version 6.0. Mol. Biol. Evol. 30: 2725-2729. http://dx.doi.org/10.1093/molbev/mst197

Thomaz SM and Bini LM (1999). A expansão das macrófitas aquáticas e implicações para o manejo de reservatórios: um estudo na represa de Itaipu. In: Ecologia de reservatórios: estrutura, função e aspectos sociais (Henry R, ed.). Botucatu, FUNDIBIO/FAPESP, São Paulo, 597-626.

Thomaz SM, Bini LM and Souza DC (1998). Biomass and maximum colonization depth of Egeria Najas Planchon (Hydrocharitaceae) at Itaipu Reservoir, Brazil. In: Management and ecology of aquatic plants. Proceedings of the 10th EWRS International Symposium on Aquatic Weeds, Lisbon, Portugal, 21-25 September 1998, 223-226.

Genetics and Molecular Research 15 (3): gmr.15038575 
Torke BM and Schaal BA (2008). Molecular phylogenetics of the species-rich neotropical genus Swartzia (Leguminosae, Papilionoideae) and related genera of the swartzioid clade. Am. J. Bot. 95: 215-228. http://dx.doi.org/10.3732/ ajb.95.2.215

Tryon RM and Tryon AF (1982). Ferns and Allied Plants. Springer-Verlang, New York.

Velásquez J (1994). Plantas Acuaticas vasculares de Venezuela. Universidasde Central de Venezuela, Caracas.

Wall DP and Herbeck JT (2003). Evolutionary patterns of codon usage in the chloroplast gene rbcL. J. Mol. Evol. 56: 673688, discussion 689-690. http://dx.doi.org/10.1007/s00239-002-2436-8

Genetics and Molecular Research 15 (3): gmr.15038575 